\title{
Analisis Pertanggungjawaban Pencemaran Lingkungan Akibat Tumpahan Minyak (Studi Kasus: Kebocoran Pipa Minyak di Teluk Balikpapan)
}

\author{
Dewi Fatmawaty ${ }^{\text {a* }}$ \\ a Program Studi Magister Ilmu Lingkungan Universitas Diponegoro, Semarang-Indonesia \\ *Email: fatmawaty.dewi@gmail.com
}

Diterima (received) 13 Desember 2019; disetujui (accepted) 1 Februari 2020; tersedia secara online (available online) 1 Februari 2020

\begin{abstract}
Environmental pollution in marine waters has a very broad impact on all life both at sea and on land. The oil spill not only affects the ecosystem, but also affects the health and economy of the surrounding community. This study aims to determine the extent of efforts to resolve cases of marine pollution due to oil spills in Balikpapan Bay. This research method uses this type of research is a normative juridical approach method which is done by examining library materials or secondary data as a basis for research by searching the regulations and literature relating to research problems. Qualitative analysis, which uses literature as a source of research data. Liability for oil spill cases in Balikpapan Bay can be carried out through civil lawsuits against parties related to pollution. In addition, it is important to immediately make arrangements regarding RZWP3K to realize harmony and synergy in the utilization of coastal areas and small islands between regional governments and related sectors.
\end{abstract}

Keywords: marine pollution; RZWP3K; liability

\begin{abstract}
Abstrak
Pencemaran lingkungan di perairan laut memiliki akibat yang berdampak sangat luas terhadap segala kehidupan baik kehidupan di laut maupun di daratan. Kejadian tumpahan minyak tersebut tidak hanya berpengaruh terhadap ekosistem, namun juga berpengaruh pada kesehatan dan perekonomian masyarakat sekitar. Penelitian ini bertujuan untuk mengetahui sejauhmana upaya penyelesaian kasus pencemaran laut akibat tumpahan minyak di Teluk Balikpapan. Metode penelitian ini menggunakan jenis penelitian ini adalah metode pendekatan yuridis normatif yang dilakukan dengan meneliti bahan pustaka atau data sekunder sebagai bahan dasar untuk diteliti dengan melakukan penelusuran terhadap peraturan dan literatur yang berkaitan dengan permasalahan penelitian. Analisis secara kualitatif, yang menggunakan bahan-bahan kepustakaan sebagai sumber data penelitian. Pertanggungjawaban kasus tumpahan minyak di Teluk Balikpapan dapat dilakukan melalui gugatan perdata kepada pihak yang terkait dengan pencemaran. Selain itu penting untuk segera dilakukan pengaturan mengenai RZWP3K untuk mewujudkan keharmonisan dan sinergi pemanfaatan wilayah pesisir dan pulaupulau kecil antar pemerintah daerah dan antar sektor terkait.
\end{abstract}

Kata Kunci: pencemaran laut; RZWP3K; pertanggungjawaban

\section{Pendahuluan}

Pencemaran lingkungan terhadap laut merupakan salah satu isu lingkungan yang mendapat perhatian dari dunia internasional. Pencemaran lingkungan di perairan laut memiliki akibat yang berdampak sangat luas terhadap segala kehidupan baik kehidupan di laut maupun di daratan dan salah satunya akan mengganggu ketersediaan sumberdaya alam baik bagi negara itu sendiri maupun bagi negara-negara lain, sehingga dalam penanganan pencemaran laut memerlukan tindakan khusus dalam pertanggungjawabannya. Sumber utama pencemaran laut biasanya berasal dari tumpahan minyak yang berasal dari kegiatan

doi: https://doi.org/10.24843/blje.2020.v20.i01.p03

(C) 2019 by the authors; Content from this work may be used under the terms of the Creative Commons Attribution 3.0 licence. Any further distribution of this work must maintain attribution to the author(s) and the title of the work, journal citation and DOI. Published under licence by Udayana University, Indonesia. 
operasional kapal, pengeboran lepas pantai (eksplorasi) maupun akibat kecelakaan kapal. Setiap tahunnya 3 sampai dengan 4 juta ton minyak bumi mencemari lingkungan laut (Hardjasoemantri, 2001).

Salah satu kasus tumpahan minyak yang terjadi di Indonesia adalah kasus tumpahan minyak di Teluk Balikpapan. Tumpahan minyak bermula pada hari Sabtu tanggal 31 Maret 2018 pukul 01.20 WITA akibat patahnya pipa penyalur dasar laut yang mengalirkan minyak mentah dari Single Point Mooring (SPM) Terminal Lawe-lawe menuju CDU IV Pertamina RU V Balikpapan. Berdasarkan data side sonar Pertamina RU V Balikpapan, patahnya pipa diduga akibat benturan jangkar kapal atau lainnya (www.pertamina.com, n.d.). Pusat Hidrografi dan Oseanografi TNI Angkatan Laut (Pushidrosal) melakukan pencitraan dasar laut di lokasi patahan untuk mengetahui penyebabnya. Survei dilakukan menggunakan 3 peralatan berupa side scan sonar, multibeam echosounder, dan magnetometer. Dari tampilan base surface, satu pipa memang patah dan bergeser sejauh 117,34 meter dan ditemukan parit bekas garukan yang diduga bekas garukan jangkar dengan panjang 498,82 meter, lebar 1,6 - 2,5 meter dan kedalaman 0,3-0,7 meter. Pada Kamis 26 April 2018, Kepolisian Daerah Kalimantan Timur yang secara resmi merilis penetapan nakhoda Kapal MV Ever Judger sebagai tersangka putusnya pipa bawah laut PT. Pertamina sehingga mengakibatkan terjadinya ceceran minyak di Teluk Balikpapan dan kebakaran di Kapal MV Ever Judger. (www.pertamina.com, n.d.)

Teluk Balikpapan terletak di tiga wilayah pemerintahan, yaitu Pemerintah Kota Balikpapan, Pemerintah Kabupaten Kutai Kartanegara, dan Kabupaten Penajam. Perairan Teluk Balikpapan memiliki banyak biota laut seperti alga, ikan, terumbu karang dan lain sebagainya (Hardwinarto, 2002). Kejadian tumpahan minyak tersebut tidak hanya berpengaruh terhadap ekosistem, namun juga berpengaruh pada kesehatan dan perekonomian masyarakat sekitar. Sebagian besar masyarakat sekitar berprofesi sebagai nelayan dan mempunyai tambak kepiting. Balikpapan yang terkenal dengan olahan kepitingnya, pasti membutuhkan pasokan kepiting yang banyak. Sedangkan banyak penambak kepiting yang membudidayakan kepitingnya langsung di laut bukan di kolam buatan, namun dengan adanya tumpahan minyak maka panen kepiting terancam gagal dan perekonomian masyarakat yang membudidayakan kepiting jadi terganggu.

Dampak terhadap ekosistem antara lain yaitu tanaman mangrove dengan perkiraan luas 34 hektare di Kelurahan Karingau RT 1 dan 2 tercemar, matinya satu ekor pesut, kegagalan panen budidaya kepiting, rusaknya empat kawasan terumbu karang, rusaknya budidaya rumput laut, dan terancam matinay lima kawasan padang lamun. Dampak tersebut bukan hanya pada ekosistem, namun juga berdampak bagi manusia antara lain masyarakat di sekitaran tumpahan minyak yang mengeluh mual dan pusing akibat bau minyak yang menyengat, lima orang nelayan yang tewas akibat kapal terbakar, satu kapal kargo juga ikut terbakar, serta sebanyak 162 nelayan terancam tidak bisa melaut serta masyarakat Kota Balikpapan dan Kabupaten Penajam Paser Utara terancam sulit untuk mendapatkan air bersih (Tempo.co, 2018).

Hutan mangrove memiliki beragam fungsi antara lain melindungi dari erosi dan abrasi pantai, sebagai tempat hidupnya beragam satwa air dan satwa darat, sebagai mitigasi dari perubahan iklim dengan menyerap $\mathrm{CO}_{2}$, dan sebagai penahan badai angin. Terumbu karang merupakan biota laut yang pertumbuhannya dipengaruhi oleh suhu yang ideal sekitar $26-28{ }^{\circ} \mathrm{C}$, dengan adanya tumpahan minyak yang menggenang di permukaan air laut akan menghambat cahaya masuk ke dasar laut. Sedangkan padang lamun adalah tanaman berbunga yang beradaptasi secara cepat pada air laut dan memiliki fungsi menjada kestabilan ekosistem laut dan kestabilan pesisir pantai dan dapat menjadi sumber makanan bagi hewan laut (Pramudyanto, 2014).

Agar kasus patahnya pipa minyak milik Pertamina di Teluk Balikpapan yang mengakibatkan tumpahan minyak di perairan laut tersebut tidak terulang kembali, perlu didorong pembentuan zonasi di lautan pembentukan zonasi di lautan berupa Rencana Zonasi Wilayah Pesisir dan Pulau-Pulau Kecil (RZWP3K) atau serupa dengan Rencata Tata Ruang Wilayah (RTRW) di daratan dalam rangka penyelesaian pertanggungjawabannya (Walhi, n.d.).

Dari berbagai dampak yang timbul akibat tumpahan minyak tersebut, maka penulis ingin mengetahui sejauhmana upaya penyelesaian kasus pencemaran laut akibat tumpahan minyak di Teluk Balikpapan. 


\section{Metode Penelitian}

Metode penelitian ini menggunakan jenis penelitian ini adalah metode pendekatan yuridis normatif. Metode pendekatan yuridis normatif adalah pendekatan yang dilakukan dengan meneliti bahan pustaka atau data sekunder sebagai bahan dasar untuk diteliti dengan melakukan penelusuran terhadap peraturan dan literatur yang berkaitan dengan permasalahan penelitian (Soerjono Soekamto dan Sri Mamudji, 2004).

Penelitian ini menggunakan data sekunder sebagai data utama. Data sekunder adalah data yang diperoleh dari penelitian kepustakaan dan dokumentasi yang merupakan hasil penelitian dan pengolahan orang lain, tulisan dan pendapat para pakar hukum internasional. Analisis data dalam suatu penelitian bertujuan untuk memberikan jawaban terhadap masalah yang diteliti, dengan terlebih dahulu diadakan pengumpulan data. Metode analisis data yang digunakan adalah analisis kualitatif, yang menggunakan bahan-bahan kepustakaan sebagai sumber data penelitian. Data-data yang telah dianalisis secara kualitatif, dalam hal ini hubungan teori yang didapat dianalisis dan dikaji untuk kemuadian disistematiskan menjadi analisis data yang disusun dalam bentuk penulisan hukum.

Penelitian hukum ini mencari kebenaran koherensi yakni adakah aturan hukum sesuai dengan norma hukum, adakah norma sesuai dengan prinsip hukum, dan apakah tindakan sesuai dengan norma hukum atau prinsip hukum (Peter Mahmud Marzuki, 2005), serta melakukan pemecahan masalah untuk memberikan preskripsi atas isu hukum yang diajukan (Dyah Octorina Susanti, 2014).

\section{Hasil dan Pembahasan}

\subsection{Rencana Zonasi Wilayah Pesisir dan Pulau-Pulau Kecil (RZWP3K)}

Undang Undang (UU) Nomor 27 Tahun 2007 jo UU Nomor 1 Tahun 2014 tentang Pengelolaan Wilayah Pesisir dan Pulau-Pulau Kecil menyebutkan bahwa Pemerintah Daerah wajib menyusun Rencana Zonasi Wilayah Pesisir Dan Pulau-Pulau Kecil (RZWP-3-K) sesuai dengan kewenangan masing-masing. Dalam UU Nomor 1 Tahun 2014 tentang Pengelolaan Wilayah Pesisir dan Pulau-Pulau Kecil pada pasal 16 ayat 1 menyebutkan bahwa pemanfaatan ruang dari sebagian perairan pesisir dan pulau-pulau kecil secara menetap wajib memiliki izin lokasi. Selanjutnya pada pasal 17 menjelaskan bahwa Izin lokasi sebagaimana dimaksud diberikan berdasarkan RZWP-3-K yang telah ditetapkan.

UU Nomor 23 Tahun 2014 tentang Pemerintahan Daerah pada pasal 14 menyebutkan bahwa penyelenggaraan urusan pemerintahan bidang kehutanan, kelautan, serta energi dan sumber daya mineral dibagi antara Pemerintah Pusat dan Daerah Provinsi. Selain itu dalam Lampiran Y menyebutkan bahwa pengelolaan ruang laut sampai dengan 12 mil di luar minyak dan gas bumi serta penerbitan izin dan pemanfaatan ruang laut di bawah 12 mil di luar minyak dan gas bumi menjadi kewenangan Pemerintah Daerah Provinsi. Hal ini berimplikasi pada kewajiban Pemerintah Daerah Provinsi menetapkan Peraturan Daerah RZWP-3-K.

Berdasarkan Hasil kajian KPK tahun 2014 tentang Sistem Pengelolaan Ruang Laut dan Sumberdaya Kelautan Indonesia yang di sampaikan dalam kegiatan Gerakan penyelamatan SDA Indonesia Sektor Kelautan menunjukkan sejumlah persoalan diantaranya yang menjadi fokus kajian KPK anatara lain adalah :

- Penataan ruang laut yang belum lengkap dan masih bersifat parsial

- Penataan perizinan Kelautan dan Perikanan

- Sistem data dan informasi terkait wilayah laut, penggunaan ruang laut dan pemanfaatan sumberdaya yang ada didalamnya, belum lengkap dan tidak terintegrasi

- Tidak terkendalinya pencemaran dan kerusakan dilaut.

Berdasarkan Kajian KPK tersebut disepakati bersama oleh KPK dan 20 Kementerian 7 lembaga dan 34 Provinsi Untuk menuntaskan persoalan di sektor kelautan salah satunya adalah Penyusunan RZWP3K di setiap provinsi. 


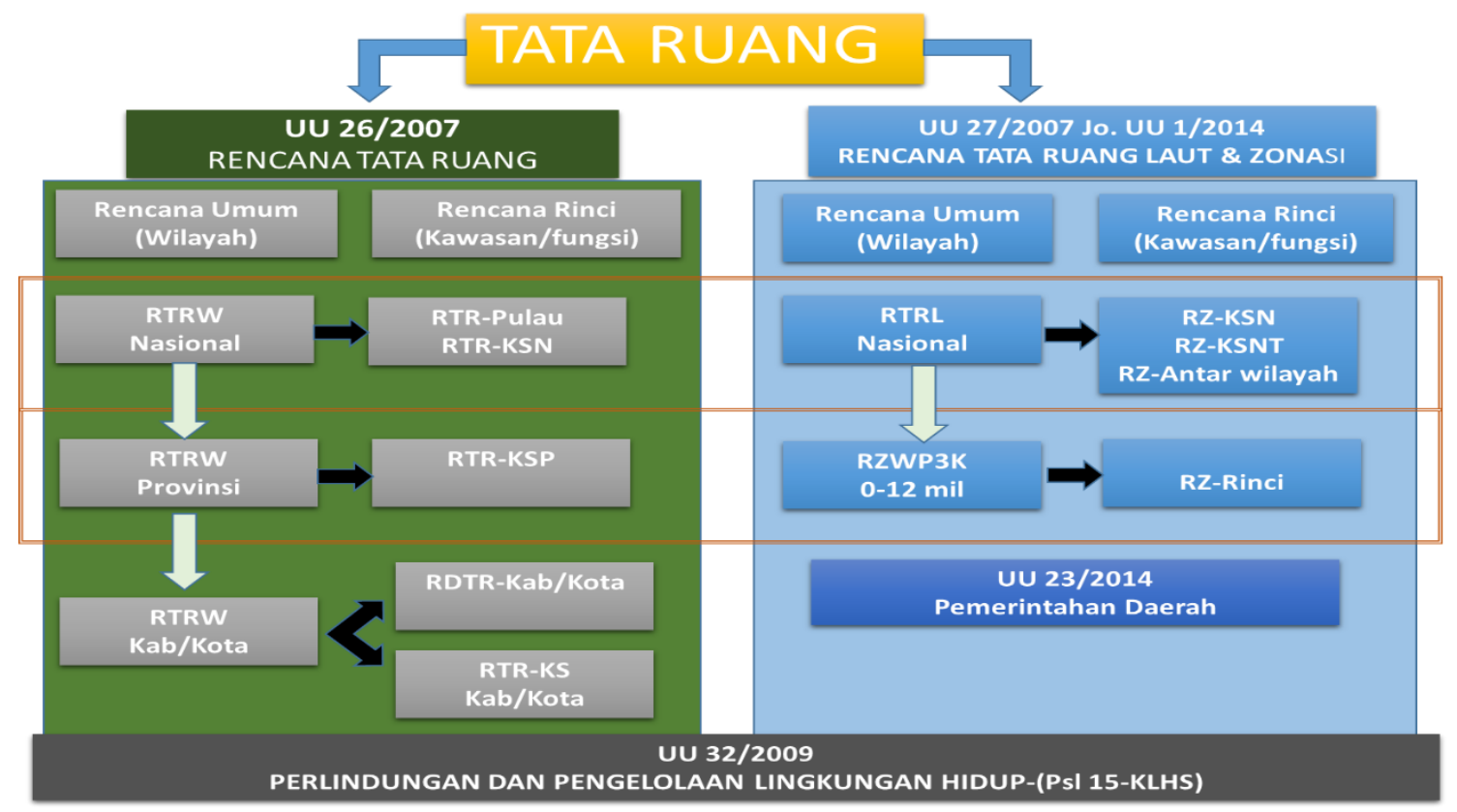

Gambar 1. Hirarki penataan ruang yang telah di amanah oleh undang -undang.

PERATURAN MENTERI KELAUTAN DAN PERIKANAN NO. 23/PERMEN-KP/2016 TENTANG PERENCANAAN PENGELOLAAN WILAYAH PESISIR DAN PULAU-PULAU KECIL

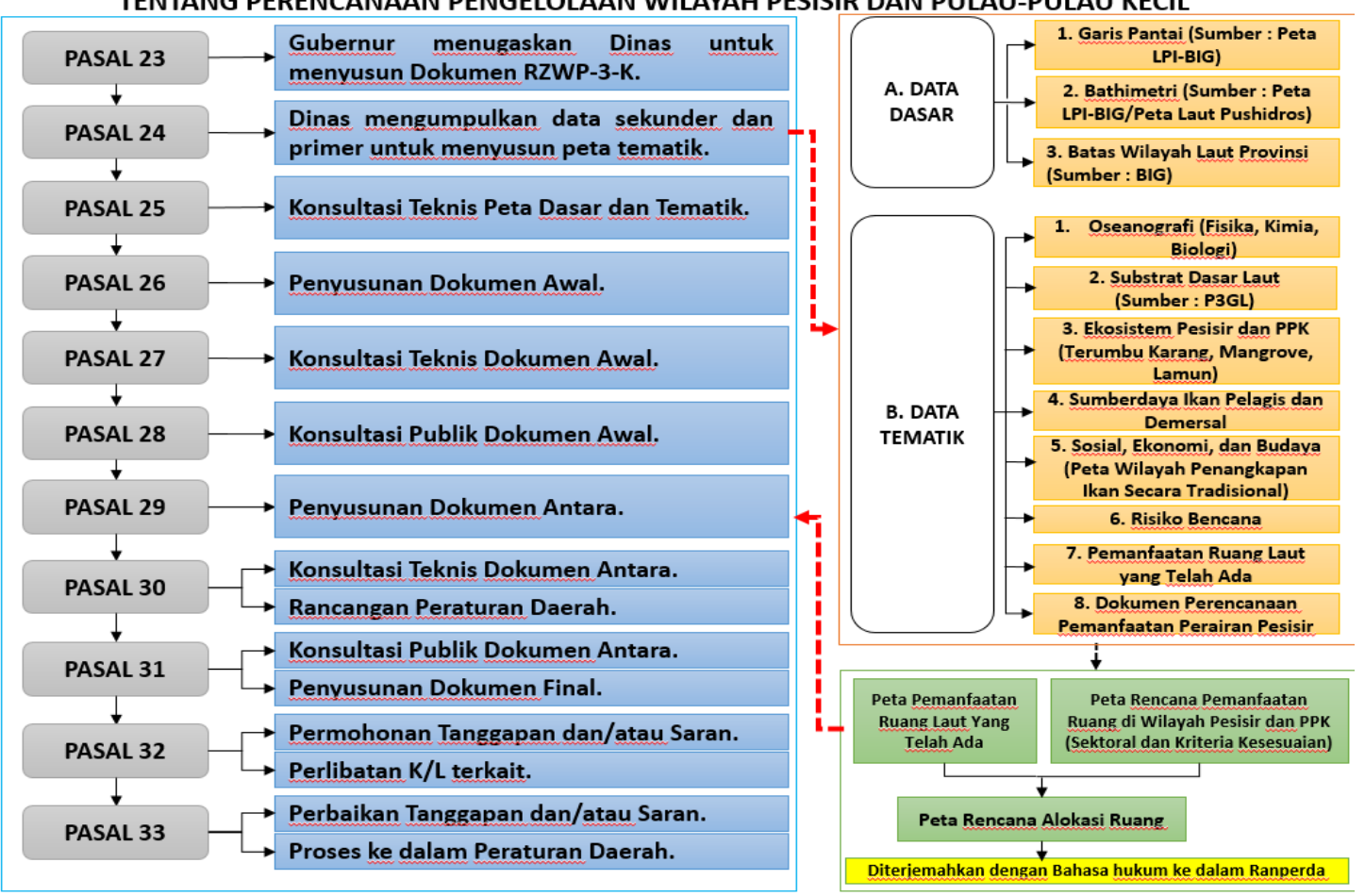

Gambar 2. Proses penyelesaian RZWP3K berdasarkan Peraturan Menteri No. 23 Tahun 2016. 
Urgensi pengaturan mengenai RZWP3K adalah untuk mewujudkan keharmonisan dan sinergi pemanfaatan wilayah pesisir dan pulau-pulau kecil antar pemerintah daerah dan antar sektor terkait. Pengaturan RZWP3K membantu mengidentifikasi dan menerapkan prioritas bagi pengembangan WP3K, misalnya untuk konservasi, industri terpadu, pariwisata bahari, transportasi laut maupun pertahanan keamanan dan untuk mencegah atau meminimalkan dampak negatif terhadap ekosistem WP3K (Sands, 2003).

Mengingat Teluk Balikpapan terletak di tiga wilayah pemerintahan, yaitu Pemerintah Kota Balikpapan, Pemerintah Kabupaten Kutai Kartanegara, dan Kabupaten Penajam. Sampai dengan saat ini Pemerintah Provinsi Kalimantan Timur sampai dengan saat ini belum menetapkan Peraturan Daerah tentang RZWP3K. Raperda RZWP3K dianggap tidak ramah lingkungan dan para nelayan yang mencari kehidupan di kawasan Teluk Balikpapan, selain itu penyusunan Raperda tidak melibatkan lapisan masyarakat nelayan sebagai pelaku utama di perairan pesisir. Konsultasi publik yang digelar pada tanggal 22 Mei 2019, dari 129 undangan diantaranya 88 undangan dari unsur pemerintah, 12 lembaga perwakilan masyarakat sipil, dan 11 perusahaan, sementara nelayan dan masyarakat pesisir sebagai masyarakat terdampak tidak diundang.

\subsection{Pertanggungjawaban Pencemaran Laut akibat Tumpahan Minyak di Teluk Kalimantan}

Dalam hukum lingkungan internasional dikenal prinsip polluter pays principle (prinsip pencemar membayar), yang secara sederhana prinsip ini mengharuskan penghitungan kerugian terhadap pihak yang menyebabkan pencemaran, yakni berupa kewajiban pembayaran dari aktivitas yang menyebabkan kerusakan dengan menggunakan instrumen ekonomi dan penerapan aturan terkait persaingan usaha dan subsidi (Sands, 2003). Namun prinsip ini harus didasarkan pada dua prinsip lainnya yaitu strict liability principle dan liability based on fault principle apabila terjadi pencemaran. Prinsip strict liabilty atau tanggung jawab mutlak adalah asas di mana pertanggungjawaban atas suatu pencemaran lingkungan tidak perlu adanya pembuktian terhadap siapa yang berperan atau yang menyebabkan suatu pencemaran ataupun unsur-unsur pencemaran, namun didasarkan pada bukti riil kerusakan yang terjadi atas suatu kejadian pencemaran itu sendiri. Sedangkan konsep liability based on fault atau fault-based liability merupakan prinsip di mana pertanggung jawaban didasarkan pada pembuktian unsur kesalahan yang dilakukan oleh pihak yang diduga sebagai pelaku pencemaran lingkungan tersebut. Hal ini menjadikan pertanggung jawaban suatu pencemaran lingkungan harus masuk dahulu dalam ranah pembuktian terhadap seberapa besar kerusakan lingkungan yang terjadi tersebut.

Penyelidikan awal pihak terkait diketemukan bahwa jangkar Kapal MV Judger yang terlepas dari pipa minyak yang bocor tersebut dapat kemudian diidentifikasi kemungkinannya anatara lain yaitu 1) faktor cuaca yang begitu buruk sehingga dapat menyeret kapal yang telah melakukan lego jangkar di wilayah perairan tersebut, 2) faktor posisi pipa yang memang terpapar sehingga tidak memperkirakan jika terjadi cuaca buruk dan tidak menghiraukan potensi pipa yang terkena bagian kapal yang melintas, 3) faktor pengaturan atau pelaporan cuaca dan lalu lintas kapal oleh otoritas kelautan atau pengatur lalu lintas kapal yang tidak memperkirakan posisi cuaca atau mengetahui potensi kapal untuk memasuki wilayah yang terdapat jalur pipa tersebut (Jawapos.com, n.d.). Faktor-faktor yang menyebabkan kebocoran pipa tersebut tidak dapat dikatakan sebagai faktor tunggal atau berdiri sendiri yang menyebabkan sulitnya untuk seketika menentukan pihak mana yang harus bertanggungjawab. Secara umum, faktor alam yang menyebabkan adanya suatu kerugian dalam bentuk infrastruktur dan ekonomi maka secara logika tidak dapat dibebankan pada satu pihak semata. Cuaca buruk yang dihadapi Kapal MV Judger merupakan faktor alam yang tidak diketahui kapan terjadi dan apa akibatnya.

Secara normatif, UU Nomor 32 Tahun 2009 tentang Perlindungan dan Pengelolaan Lingkungan Hidup (UU PPLH) menganut prinsip tanggung jawab mutlak atau strict liability, dimana dalam kasus tumpahan minyak di Teluk Balikpapan ini yang diakibatkan lego jangkar Kapal MW Judger yang dilakukan dalam keadaan darurat dan mengenai pipa minyak PT. Pertamina menjadi tidak relevan untuk diterapkan. Hal tersebut dikarenakan berbagai faktor penyebab anatara lain tindakan lego jangkar dalam keadaan darurat karena cuaca buruk, klasifikasi kapal hingga jenis pertanggungjawaban yang akan dikenakan tidak sesuai unsur atau perspektif dalam Civil Liability Convention 1969 dan UU PPLH tentang strict liability itu sendiri. 
Konsep pertanggungjawaban atas pencemaran laut oleh minyak ini apabila melihat pada Civil Liability Convention 1969 terdiri dari 4 hal utama yang menjadi perhatian, yaitu:

1. Bahaya dari pencemaran minyak melekat dalam transportasi minyak dengan kapal melalui laut;

2. Kebutuhan untuk memastikan adanya kompensasi yang layak terhadap masyarakat yang mengalami kerugian dari pencemaran yang dihasilkan dari kebocoran atau bongkar muat dari kapal;

3. Keinginan untuk penyamaan desain peraturan dan prosedur untuk menemukan pertanggungjawaban dan penyediaan ganti rugi yang layak; dan

4. Keinginan pemerintah agar lebih percaya diri dalam mengambil tindakan awal dan tindakan yang menentukan.

Konsep diatas merujuk pada pencemaran yang dilakukan oleh kapal pengangkut minyak. UU PPLH sendiri secara eksplisit hanya mengakui pertanggungjawaban mutlak dalam setiap kejadian pencemaran lingkungan yang terjadi, konsekuensinya adalah potensi penyangkalan dari pihak tertentu terutama yang dikatakan terlibat dalam pencemaran lingkungan yang sudah terjadi.

Pencemaran lingkungan di Teluk Balikpapan tersebut tetap memerlukan pertanggungjawaban oleh pihak-pihak yang diduga terlibat dalam peristiwa bocornya pipa minyak yang mencemari laut. Pertanggungjawaban dari pihak kapal, yang patut diduga keras sebagai pihak yang bertanggungjawab atas bocornya pipa minyak perlu dilakukan penyelidikan lebih dalam, yang pada akhirnya bahwa pertanggungjawaban kasus ini tidak dapat dilakukan secara strict liability. PT Pertamina sebagai pemilik pipa minyak perlu juga diperiksa apakah dalam pemasangan pipa tersebut telah memperhitungkan sedemikian detailnya apabila dalam keadaan darurat terjadi kemungkinan dapat bocornya pipa oleh sebab apa pun.

Gugatan perdata merupakan satu-satunya cara yang mungkin untuk meminta pertanggungjawaban atas pencemaran laut ini, karena tidak adanya faktor tunggal yang dapat disalahkan dalam peristiwa tersebut. UU PPLH memungkinkan untuk Pemerintah atau Pemerintah Daerah memiliki hak gugat bilamana terjadi pencemaran lingkungan sebagaimana diatur dalam Pasal 90. Hal tersebut dilakukan atas nama untuk menjaga dan meminta ganti rugi atas kelestarian lingkungan yang dirugikan atas peristiwa tersebut, maka dapat terjadi skenario gugatan tanggung renteng di antara kapal MV Judger dan PT Pertamina jikalau memang di antara keduanya telah nyata-nyata kemudian terbukti terdapat prosedur darurat yang tidak dijalankan.

Konsep tanggung renteng diatur dalam KUH Perdata Indonesia dalam Pasal 1278 dan 1280 yang juga dapat diterapkan dalam kasus perbuatan melawan hukum. Konsep gugatan tanggung renteng dan pengenaan dalil perbuatan melawan hukum sebagaimana dirumuskan dalam pasal $1365 \mathrm{BW}$ ini tidak lain karena sebagaimana melihat faktor uraian di atas ketiadaan kesalahan tunggal dalam pencemaran laut tersebut menjadikan perkara ini menjadi hal yang rumit, namun satu hal yang pasti dalam pencemaran ini ialah obyek pencemaran telah merugikan masyarakat termasuk negara yang harus mempergunakan aparaturnya untuk sesegera mungkin melakukan tanggap darurat dengan melokalisir hingga menetralisir pencemaran agar tidak meluas ke wilayah lautan lain. Namun jelas dalam pencemaran tidak mungkin terjadi tanpa adanya prosedur yang dilanggar oleh pihak-pihak yang terkait dengan pencemaran tersebut dan murni terkait dengan force majeuer saja.

Gugatan tanggung renteng dalam PMH ini selain mendapatkan payung hukum dari sisi lingkungan di mana dimungkinkan untuk melakukan gugatan perdata, pihak yang merasa dirugikan atas terjadinya sesuatu peristiwa biasanya berada diposisi yang minim informasi pihak mana yang menyebabkan adanya kerugian yang dia derita. Terlebih dalam sengketa dengan multi pihak di dalamnya, gugatan tanggung renteng dalam PMH tidak mengharuskan penggugat untuk tahu pasti pihak mana yang menyebabkan kerugian yang ia derita.

Pandangan selanjutnya yang dapat digunakan dalam penyelesaian sengketa terkait kasus pencemaran laut ini ialah pemberian pengecualian terkait dengan bentuk atau siapa yang langsung dikenakan pertanggungjawaban atas peristiwa tersebut. Sebagaimana dijelaskan di atas bahwa setiap tindakan penegakan hukum negara satu terhadap suatu peristiwa yang bersentuhan dengan subyek hukum negara lain haruslah dilaksanakan dengan berbagai pertimbangan yang bukan berarti hal tersebut merupakan intervensi terhadap proses hukum suatu negara, namun merupakan suatu bentuk upaya penyeimbang jikalau melihat ketiadaan faktor tunggal dalam peristiwa ini. Seluruh pihak yang menyebabkan terjadinya 
pencemaran laut harus dimintai secara tanggung renteng untuk upaya pemulihan lingkungannya. Adanya kualifikasi sebenar-benarnya pelaku atau perpetrators dan serious or grave breaches yang tidak mungkin ditemukan dalam peristiwa ini harus dikaitkan dengan peranan masing-masing pihak dalam pencemaran yang mengarah pada tanggung renteng tersebut, mulai dari kapal, otoritas terkait, termasuk pemerintah dalam hal ini Pertamina, sehingga diharapkan keseimbangan dapat dicapai di antara seluruh pihak untuk menyelesaikan dan pemulihan dari pencemaran tersebut.

\section{Simpulan}

Berdasarkan hasil analisis dan pembahasan maka dapat disimpulkan bahwa pertanggungjawaban atas kasus pencemaran lingkungan akibat tumpahan minyak di Teluk Balikpapan tidak dapat diakukan melakukan mekanisme strict liability dikarenakan ketiadaan faktor tunggal yang menjadi penyebab pencemaran dan adanya force majeure dalam peristiwa tersebut. Mekanisme pertanggungjawaban yang dimungkinkan adalah melalui gugatan perdata kepada pihak yang terkait dengan pencemaran yaitu Kapal MV Judger dan PT. Pertamina Persero secara tanggung renteng oleh Pemerintah atau Pemerintah Daerah sebagai pihak yang paling berkepentingan untuk menjaga laut dari pencemaran dan sebagai bentuk kompensasi dari tindakan darurat yang dilakukan dalam mencegah makin luasnya pencemaran dan ganti rugi yang sesuai.

Selain itu pentingnya pengaturan mengenai RZWP3K untuk mewujudkan keharmonisan dan sinergi pemanfaatan wilayah pesisir dan pulau-pulau kecil antar pemerintah daerah dan antar sektor terkait, untuk dapat mengidentifikasi dan menerapkan prioritas bagi pengembangan WP3K, misalnya untuk konservasi, industri terpadu, pariwisata bahari, transportasi laut maupun pertahanan keamanan dan untuk mencegah atau meminimalkan dampak negatif terhadap ekosistem WP3K mengingat Teluk Balikapapan terletak di tiga wilayah pemerintahan dan berdampak pada dua wilayah yaitu Kota Balikpapan dan Kabupaten Penajam.

\section{Ucapan terimakasih}

Ucapan terimakasih penulis sampaikan kepada Dr. Ir. Joesron Alie Syahbana, M. SP selaku dosen mata kuliah Perencanaan Tata Ruang dan Lingkungan pada Magister Ilmu Lingkungan Universitas Diponegoro Semarang.

\section{Daftar Pustaka}

Dyah Octorina Susanti, A. E. (2014). Penelitian Hukum (Legal Research). Jakarta: Sinar Grafika.

Hardjasoemantri, K. (2001). Hukum Lingkungan Hidup di Indonesia. Jakarta: Program pasca Sarjana Hukum Universitas Indonesia.

Hardwinarto, S. (2002). Kajian Erosi dan Sedimentasi pada DAS Teluk Balikpapan Kalimantan Timur.

Jawapos.com. (n.d.). Kasus Putusnya Pipa Pertamina , Kapal MV Ever Judger Disita. pp. 1-10.

Peter Mahmud Marzuki. (2005). Penelitian Hukum (Edisi revisi). Jakarta: Prenada.

Pramudyanto, B. (2014). Pengendalian Pencemaran dan Kerusakan di Wilayah Pesisir. Jurnal Lingkar Widyaiswara, (4), 21-40. Retrieved from www.juliwi.com

Republik Indonesia. (1874). Kitab Undang-Undang Hukum Perdata (Burgerlijk Wetboek voor Indonesie). Staatsblad Tahun 1847 Nomor 23.

Republik Indonesia. (1978). Keputusan Presiden Nomor 18 Tahun 1978 Tentang Mengesahkan "International Convention on Civil Liability For Oil Pollution Damage". Lembaran Negara Republik Indonesia Tahun 1978. Jakarta, Indonesia: Sekretariat Negara Republik Indonesia.

Republik Indonesia. (2009). Undang-Undang Nomor 32 Tahun 2009 Tentang Perlindungan dan Pengelolaan Lingkungan Hidup. Lembaran Negara Republik Indonesia Tahun 2009 Nomor 140. Jakarta, Indonesia: Sekretariat Negara Republik Indonesia.

Republik Indonesia. (2014). Undang-Undang Nomor 1 Tahun 2014 Tentang Perubahan Atas UndangUndang Nomor 27 Tahun 2007 Tentang Pengelolaan Wilayah Pesisir dan Pulau-Pulau Kecil. 
Lembaran Negara Republik Indonesia Tahun 2014 Nomor 2. Jakarta, Indonesia: Sekretariat Negara Republik Indonesia.

Republik Indonesia. (2014). Undang-Undang Nomor 23 Tahun 2014 Tentang Pemerintah Daerah. Lembaran Negara Republik Indonesia Tahun 2014 Nomor 244. Jakarta, Indonesia: Sekretariat Negara Republik Indonesia.

Republik Indonesia. (2016). Peraturan Menteri Kelautan dan Perikanan Nomor 23 Tahun 2016 Tentang Perencanaan Pengelolaan Wilayah Pesisir dan Pulau-Pulau kecil. Lembaran Negara Republik Indonesia Tahun 2016 Nomor 1138. Jakarta, Indonesia: Sekretariat Negara Republik Indonesia.

Sands, P. (2003). Principles of International Environmental Law. Cambridge: Cambridge University Press. Soerjono Soekamto dan Sri Mamudji. (2004). Penelitian Hukum Normatif Suatu Tinjauan Singkat. Jakarta: PT. Raja Grafindo Persada.

Tempo.co. (2018, January 19). Dampak Ekologis Tumpahan Minyak Pertamina di Teluk Balikpapan. Tempo.Co, pp. 1-6.

Walhi. (n.d.). Tumpahan Minyak di Balikpapan akan Berdampak Panjang. Tempo.Co, pp. 4-7.

www.pertamina.com. (n.d.). Sedang Dalam Pemulihan Menata Kembali Teluk Balikpapan. Energia. 